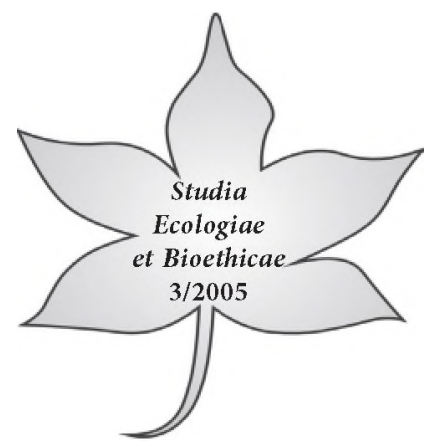

\title{
Relacja człowieka do jego wytworów w aspekcie etyki środowiskowej
}

\begin{abstract}
1. Uwaga wstępna
Przedmiotem etyki powinno być nie tylko wartościowanie różnych form działań ludzkich, ale również ocena rezultatów tych działań. Mówiąc o rezultatach działalności człowieka, mam na myśli - oprócz ich skutków i konsekwencji logicznych - także materialne i duchowe produkty naszych działań, czyli różnego rodzaju artefakty. Nie sposób, oczywiście, w jednym artykule odnieść się do całokształtu problemów ani do ewaluacji wszystkich skutków naszych działań. Dlatego ograniczam się wyłącznie do jednej sprawy, a mianowicie do odpowiedzialności za nadmierne nasycanie środowiska życia ludzi wytworami techniki, które wykorzystywane są jako protezy do wspomagania organizmu ludzkiego oraz intelektu. Ten rodzaj odpowiedzialności mieści się w obszarze zainteresowań etyki środowiskowej, która odnosi się do relacji „człowiek-środowisko” i dlatego jest czymś nowym i obszerniejszym w porównaniu z tradycyjnie rozumianą odpowiedzialnością moralną, zazwyczaj ograniczaną do obszaru relacji „człowiek-człowiek”. Bowiem środowisko rozumie się nie tylko jako otoczenie społeczne, ale też przyrodnicze. Wydaje mi się, ze kwestia odpowiedzialności za masową produkcję wszelkiego rodzaju artefaktów, a w szczególności protez, jak i masowe posługiwanie się nimi jest sprawą niezwykle ważną i godną poważnego potraktowania w debacie etycznej.
\end{abstract}

\section{Człowiek w środowisku artefaktów}

Współczesne środowisko życia - jak nigdy przedtem - coraz bardziej nasycane jest wytworami ludzkiej wiedzy i działalności technicznej. Bezpośrednimi wytworami techniki są obiekty materialne, a wytworami wiedzy - obiekty idealne. ${ }^{1}$ Jedne i drugie obce są naturalnemu środowisku życia, są czymś sztucznym,

Pośrednimi produktami wiedzy dzięki zastosowaniu jej w technice są przedmioty materialne. 
co ludzie powołują do istnienia i wprowadzają w świat rozwijając kulturę. Są to byty sztuczne, czyli artefakty. ${ }^{2}$ Równolegle ze wzrostem liczby artefaktów rośnie ich rola i znaczenie w naszym życiu. Z jednej strony, umożliwiają nam one przeżycie $w$ trudnych sytuacjach, ale $z$ drugiej strony, niosą ze sobą poważne zagrożenia dla naszego życia oraz dla przetrwania gatunku ludzkiego. Z jednej strony, postęp wiedzy i techniki czyni z nas istoty bardziej rozumne i doskonalsze pod względem sprawnościowym i pozwala pokonywać tzw. siły przyrody oraz różne ułomności, niedoskonałości i choroby, a z drugiej strony, - jakby paradoksalnie - przyczynia się do redukcji racjonalności ludzi (do masowego ogłupiania), czyni $\mathrm{z}$ nas istoty ułomne i generuje nowe groźniejsze choroby. ${ }^{3}$

Jedna grupa zagrożeń związana jest z tym, że postęp techniki uczynił z nas istoty tak bardzo zależne od produktów techniki, że nie jesteśmy w stanie żyć bez ich pomocy. Przeto postęp ten czyni z nas kaleki, coraz bardziej niesprawne pod względem biologicznym, które chcąc przeżyć, muszą wspierać się na kulach wytworów techniki i korzystać z różnego rodzaju protez. Słowo „proteza” rozumiem w szerokim sensie jako każde urządzenie techniczne, które zastępuje nasze cielesne oraz intelektualne narządy oraz ich funkcje. Umożliwiają one poprawne funkcjonowanie w środowisku przyrodniczym i społecznym. Protezami są w szczególności sztuczne kończyny, oczy, kule, aparaty słuchowe, okulary, implanty itd., ale też środki transportu i łączności (samochody, telefony komórkowe itp.) oraz urządzenia wykorzystywane w zarządzaniu, reklamie i polityce (techniczne środki manipulacji społecznej). Protezą jest to wszystko, co wykonując różne czynności za nas, czyni lekkim nasze życie i dzięki czemu stajemy się bardziej wydajni w sensie technicznym lub ekonomicznym. Dysponowanie coraz większą liczbą protez i coraz bardziej skomplikowanymi protezami przyczynia się do przyspieszonej degeneracji biologicznej człowieka, ponieważ tak naprawdę czyni go coraz słabszym w takich sytuacjach, gdy pozbawiony protez zdany jest na siły własnego organizmu. Bowiem bez posługiwania się protezami - jako organizm biologiczny - nie jest już w stanie odpowiednio reagować na bodźce, funkcjonować ani przeżyć. Postęp w dziedzinach nauki i techniki, który miał i nadal ma zapewniać ludziom przeżycie, w rzeczywistości zmniejsza szansę na to. Za sprawą postępu techniki nasze środowisko życia zapełnia się coraz bardziej artefaktami. Środowisko naturalne, czyli nieskażone działalnością ludzi, stopniowo przekształca się w sztuczne i jest coraz bardziej „zaśmiecane” produktami tech-

\footnotetext{
2 Oczywiście, można zastanawiać się nad tym, czy w ogóle technika i wiedza są czymś naturalnym dla ludzi, czy nie, i czy w związku z tym elementy sztuczne, wprowadzane do naszego środowiska życia, po pewnym czasie stają się naturalnymi, a sztuczne środowisko z czasem przekształca się w naturalne. Nie jest to jednak tutaj takie ważne.

O postępującej redukcji racjonalności w miarę ewolucji wiedzy pisałem w artykule „Are we really more rational?” (W: „World Affairs - The Journal of International Issues”, Vol. VII, No. 3, 2003).
} 
niki. Mamy więc do czynienia z taką oto sytuacją: żyjemy wśród coraz większej liczby bytów sztucznych, bez których nie możemy się obyć, jeśli w ogóle chcemy żyć, które w wyniku swoistej alienacji uzyskują przewagę nad nami i którym bezwiednie podporządkowujemy się. Teraz ludzie - jak nigdy wcześniej w historii - wymagają coraz większego i bardziej przemyślnego wspomagania technicznego swego życia i swych działań. Surowce naturalne zastępujemy sztucznymi, wyposażamy nasze narządy zmysłowe w różne „przedłużacze” i „uczulacze” (aparaty słuchowe, głośniki, okulary, lunety, mikroskopy itd.), nie potrafimy komunikować się bez urządzeń elektronicznych, oświetlenie naturalne zastępujemy sztucznym, do poruszania się potrzebne są nam różne techniczne środki transportu, ubieramy się w sztuczne tkaniny i skóry, spożywamy technicznie preparowaną (genetycznie modyfikowaną) i syntetyczną żywność, podtrzymujemy swe życie dzięki środkom farmaceutycznym, sztucznym narządom i przeszczepom organów, na razie naturalnych, a niedługo sztucznych (biohybrydowych). Być może, w nie tak odległej przyszłości, uda się stworzyć jakiegoś „sztucznego człowieka”cyborga (cybernetic organism) ${ }^{4}$. Mimowolnie, niezwykle silnie uzależniliśmy się egzystencjalnie od tego, co sztuczne i popadliśmy w prawdziwą niewolę artefaktów. Ich istnienie stało się warunkiem koniecznym do istnienia ludzi. Inaczej mówiąc, $\mathrm{z}$ własnej woli staliśmy się nie tylko niewolnikami artefaktów, ale również ich zakładnikami. ${ }^{5}$

Druga grupa zagrożeń wynikających z zapełniania środowiska życia bytami sztucznymi związana jest z chęcią oraz z koniecznością dorównywania im pod każdym względem, z dążeniem do upodobniania się do nich. Pod presją uwarunkowań ekonomicznych wymogiem chwili, stało się naśladowanie przez nas wytworzonych przez siebie urządzeń technicznych i maksymalne naśladowanie ich przede wszystkim ze względu na sprawność (wydajność). Z tej racji twierdzę, że ewolucja gatunku ludzkiego zmierza do mechanomorfizacji ludzi. Ta tendencja ewolucji podyktowana została przede wszystkim względami ekonomicznymi, a w szczególności obłąkańczą pogonią za zyskiem. Staramy się uzyskać takie parametry recepcji, odporności, precyzji, szybkości, elastyczności, wielofunkcyjności, pamięci itp., jakie właściwe są najwyżej rozwiniętym maszynom, to jest komputerom i robotom. Dlatego, od pewnego czasu, kontynuowana jest szaleńcza rywalizacja człowieka z techniką nie zważając na zgubne tego skutki, oczywiście dla nas, a nie dla techniki. Upodobnianie się ludzi do maszyn (komputer też jest maszyną, tylko o wiele bardziej skomplikowaną od innych)

4 Ostatnio wynaleziono w Uniwersytecie w Tokio skórę elektroniczną dla robota, która jest tak wrażliwa na dotyk jak skóra człowieka. (1. Ph. Ball, Robots get sensitive, http://www.ntech.t.u-tokyo.ac.jp; 2. Japanische Wissenschaftler haben eine elektronische Haut für Roboter entwickelt, W: „Newsletter Internet \& Telekommunikation", 5.7.2004).

5 Zob. B. Bläsing, Muskel und Maschine verschmelzen, W: „Die Welt“,12. Mai 2005. 
przyczynia się do biologicznej degradacji gatunku ludzkiego. Po pierwsze, ludzie przekazując maszynom swoje istotne cechy gatunkowe, sami (na własne życzenie) wyzbywają się ich, a przynajmniej cechy te ulegają znacznej redukcji. A po drugie, upodobnianie się ludzi do maszyn czyni z nich w końcu istoty maksymalnie naśladujące zachowanie się oraz funkcjonowanie maszyny, czyli istoty, które kierują się racjonalnością zredukowaną do zwykłej, zimnej kalkulacji oraz takie, których sfera duchowa i emocjonalną ulega wskutek tego mocnemu ograniczeniu. W rezultacie postępującej mechanomorfizacji ludzie nabywają coraz szybciej (być może w postępie geometrycznym) cechy maszyn: machinalnie zachowują się, podejmują decyzje i działają. Przekształcają się stopniowo w istoty maszynopodobne (cyborgi) czy w ludzi-maszyny i tak jak maszyny popadają w coraz silniejsze uwarunkowania deterministyczne. Wskutek tego stają się łatwym łupem różnej maści manipulatorów społecznych, którzy pociągając za odpowiednie nitki wprawiają ich podobnie jak kukiełki w z góry zaprogramowane ruchy, w swoisty „taniec chochołów”. Manipulatorzy ci, którzy w istocie są przedstawicielami różnorakiej władzy i dyktatorami narzucającymi swoją wolę milionowym rzeszom, wykorzystują wszelkie możliwe metody oraz środki, jakich dostarcza nowoczesna wiedza i technika, w tym także artefakty, niezależnie od ocen moralnych, a więc w zasadzie bezkarnie. A paradoksalnie i perfidnie łudzą ludzi co do wolności głosząc hasła liberalizmu i indywidualizmu, a także podkreślając znaczenie osobowości i wmawiając ludziom posiadanie wolnej woli i kierowanie się nią wbrew temu, z czym spotykamy się na co dzień rzeczywistość naszej rzeczywistości społecznej.

Rozwój nauki i techniki oraz związany z nim gwałtowny wzrost liczby artefaktów mających ułatwić nam codzienne życie coraz bardziej staje się przekleństwem nie tylko dla biosfery, ale także dla nas samych. Artefakty jako byty wprowadzane sztucznie do biosfery, przyczyniają się - za pośrednictwem ludzi, którzy posługują się nimi - w zastraszającym tempie do postępującej degradacji środowiska we wszystkich jego elementach. Tak na przykład wskutek zaburzenia równowagi w przyrodzie spowodowanej przez człowieka nasycającego przyrodę artefaktami wydłuza się lista chorób cywilizacyjnych i pojawiają się nowe mutacje chorobotwórczych mikroorganizmów odpornych na leki. Trudno to uznać za zemstę ze strony przyrody (przyrodzie obca jest zemsta), raczej za próbę odreagowania (samoobrony) jej na ingerencję ludzi produkujących byty sztuczne, które między innymi służą jako potężne środki ujarzmiania przyrody. A zatem, artefakty - wytwory naszego intelektu i naszych rąk - zwracają się w końcu przeciwko nam jako jednostkom oraz jako gatunkowi, ponieważ zamiast być nam podporządkowanymi i służý naszemu bezpiecznemu rozwojowi wywołują przeciwstawne skutki. I to właśnie zmusza nas do tego, by poświęcić im więcej uwagi w różnych aspektach. 
W związku ze wzrostem konsumpcji artefakty wytwarzane są w coraz większych ilościach przede wszystkim w krajach bardziej rozwiniętych gospodarczo. ${ }^{6}$ Wskutek tego, od pewnego czasu, w naszym środowisku znajduje się wiele więcej bytów sztucznych niż naturalnych i daje się zauważyć dalsze pogłębianie się tej dysproporcji. Coraz bardziej sztuczność przeważa nad naturalnością, wskutek czego nazwa ,środowisko naturalne” stała się mylącą i na dobrą sprawę pustą, bo nie znajduje już pokrycia w rzeczywistości. Tylko bardzo ograniczone, szczątkowe obszary naszego globu są jeszcze obszarami „naturalnymi”, czyli nieskażonymi techniczną działalnością ludzi oraz wpływami cywilizacji.

Coraz bardziej przyzwyczajamy się do przebywania pośród sztuczności, a to, co sztuczne, przestaje nas razić i nawet nie jest już odczuwane przez nas jak coś obcego albo jako coś nienaturalnego. To, co w naszym otoczeniu odczuwamy jako sztuczne, w odczuciu następnych pokoleń będzie uznawane za naturalne. Byty sztuczne ulegają z czasem jakby naturalizacji w tym sensie, że przejmując role bytów naturalnych przekształcają się w naszym subiektywnym odczuciu w byty naturalne. Już teraz jest tak, że to, co sztuczne, często miesza się nam z tym, co naturalne. A w miarę postępu cywilizacyjnego - wiedzy i techniki - coraz trudniej będzie odróżniać jedno od drugiego. Mimo to ciągle jeszcze mamy świadomość tego, że to, co sztuczne, to coś innego od tego, co naturalne, ponieważ wykazuje odmienne cechy, rządzi się innymi prawami i mechanizmami, inaczej jest przez nas postrzegane oraz oceniane i inaczej oddziaływa na nas. Artefakty mają przecież inną istotę i są szczególną klasą bytów, odmiennych od bytów naturalnych. ${ }^{7}$ Progresywna substytucja naturalności przez sztuczność jest czymś całkiem oczywistym.

Kryzys ekologiczny pojawia się zazwyczaj wtedy, gdy równowaga między człowiekiem a jego środowiskiem ulega znacznemu zakłóceniu. Potęgujące się nasycenie środowiska sztucznymi bytami i wymykanie się ich spod kontroli człowieka powoduje zachwianie równowagi między człowiekiem a środowiskiem artefaktów. Wskutek tego mamy teraz do czynienia ze specyficzną nieznaną wcześniej odmianą kryzysu ekologicznego.

6 O Ilości wytwarzanych artefaktów można pośrednio wnioskować z liczby odpadów. Wedle światowych statystyk jeden mieszkaniec produkuje w ciągu roku od 250 a 300 kg odpadów (Polska) do $1000 \mathrm{~kg}$ (Japonia). Możliwe, że co najmniej tyle samo artefaktów przypada też na jednego mieszkańca.

Konieczne jest zajęcie się jak najszybciej artefaktami, które są specyficzną klasą bytów, w aspekcie ontologii. Chodzi o ukazanie istoty bytów sztucznych, tak materialnych jak i idealnych, a w pierwszym rzędzie o odpowiedź na pytania:

„Czym jest artefakt i co go różni od bytu naturalnego?”

„Czy ontologia klasyczna jest w stanie dobrze opisać artefakty?"

„Czym charakteryzuje się rzeczywistość artefaktów?”. 


\section{Zagrożenia związane ze wzrostem artefaktów w obszarze kultury duchowej}

Artefaktami - zgodnie ze znaczeniem słownikowym - są wytwory ludzkie należące do sfery kultury materialnej i duchowej.

W obszarze kultury materialnej większość naszych wytworów to obiekty makroskopowe, ale coraz więcej pojawia się mikroskopowych, to znaczy takich, które są produktami rozwijającej się nanotechnologii i to właśnie ich rola w naszym życiu wzrasta coraz bardziej. O ile produkty makrotechniki są zwykłymi bytami makroskopowymi i dają się wystarczająco dobrze opisywać i badać w ramach ontologii klasycznej ${ }^{8}$, to produkty nanotechniki już nie. Są one na ogół bytami nieskończenie małymi, do których badania nie wystarczają i nie na wiele się zdają klasyczne teorie naukowe i ontologia klasyczna.

Bardziej skomplikowana sytuacja występuje w obszarze wytworów ludzkich w obszarze kultury duchowej. (Świat byłby o wiele prostszy i przejrzystszy, gdyby nie kultura!) Bowiem tutaj artefakty występują w postaci językowej (język, mity, legendy), behawioralnej (ceremonie, rytuały, zwyczaje) i wirtualnej (wirtualne postacie, szablony stosowane w technologii grafiki i w fotografii komputerowej).

Tak samo, jak artefakty techniki zaśmiecają nasze naturalne środowisko, tak artefakty kulturowe zaśmiecają środowisko kulturowe. Zaśmiecanie to produkcja i gromadzenie odpadów. Wśród artefaktów są takie, które są niezbędne do życia i takie, bez których można się obyć. Jeśli mówię o zaśmiecaniu, to mam na myśli artefakty produkowane w nadmiarze, ponad zwykłe potrzeby. $W$ miarę rozwoju cywilizacji rośnie liczba artefaktów niezbędnych do życia. A jednocześnie rośnie też - i chyba o wiele bardziej - liczba tych zbytecznych. W ogóle mamy do czynienia z postępującą hiperprodukcją artefaktów w sferze kultury materialnej i duchowej, podobnie zresztą jak nadprodukcją dóbr konsumpcyjnych. A wraz z tym rośnie przewaga sztuczności nad naturalnością.

Kilka sztuczności w dziedzinie kultury duchowej zasługuje na szczególną uwage.

Po pierwsze, sztuczny język, czy raczej sztuczne języki. Chodzi tu głównie o języki tworzone przez technologie, czyli tzw. języki techniczne, specyficzne dla poszczególnych obszarów techniki, a w szczególności o język informatyczny albo - prościej mówiąc - o żargon komputerowy. Ten język sztuczny robi ostatnio zawrotną karierę $w$ wyniku komputeryzacji rozmaitych sfer życia oraz dzięki globalizacji. Chodzi tu także o język reklamy, który plasuje się chyba na drugim miejscu pod względem upowszechniania. Do tego dochodzą jeszcze języki specjalistyczne rozmaitych dyscyplin naukowych, a także języki różnych subkultur.

\footnotetext{
8 "Ontologią klasyczną" nazywam teorię bytów namacalnych o rozmiarach makroskopowych (porównywalnych z gabarytami człowieka) i dostatecznie dobrze opisywanych za pomocą klasycznych teorii naukowych.
} 
Język jest nie tylko narzędziem służącym do porozumiewania się ludzi ze sobą, ale do myślenia i wyrażania swych stanów psychicznych oraz do manifestacji swych postaw, poglądów stosunku do otoczenia itd. Z tej racji odgrywa on niezmiernie doniosłą rolę w naszym życiu. Język, jakim posługujemy się na codzień, zawiera składniki języka naturalnego oraz sztucznego. Jednak ostatnio daje się zauważyć znaczna i rosnąca przewaga komponentów sztucznych, z których wiele kwalifikuje się jako ,śmieci”. Wnikanie elementów języków sztucznych i związane z tym zaśmiecanie języka naturalnego stale towarzyszyło rozwojowi cywilizacji. Niemniej jednak przełom nastąpił najpierw w dziewiętnastym wieku w związku $\mathrm{z}$ wkroczeniem ludzkości w erę industrializacji i scjentyzmu, a ostatnio, w dwudziestym wieku, $w$ związku $z$ internetyzacją i globalizacją. W pierwszym przypadku mieliśmy do czynienia $\mathrm{z}$ rozwojem nowomowy wynikającym z przenoszenia terminów technicznych i naukowych do języka codziennego użytku w zasadzie w obszarach lokalnych, a w drugim - z przenoszeniem wyrażeń $\mathrm{z}$ języka komputerowego oraz języka reklamy i to na skalę globalną. Wypieranie języka naturalnego przez sztuczny pociąga za sobą co najmniej dwa skutki negatywne. Po pierwsze, zastępuje się wyrażenia naturalne sztucznymi, wskutek czego zmusza się ludzi do wyrażania swych naturalnych emocji, myśli, postaw, stanów itp. za pomocą wyrażeń technicznych lub żargonowych oraz do komunikowania się za pomocą swoistych grypsów. W wielu wypadkach myślimy językiem technicznym i tym samym naśladujemy „myślenie" maszyn. Po drugie, zaśmieca się coraz bardziej język naturalny (literacki, poetycki) dziwnymi wyrażeniami technicznymi oraz bezsensownymi zwrotami reklamowymi. W pierwszym rzędzie wynaturzeniu ulega język masmediów, a za jego pośrednictwem nasz język potoczny.

Po drugie, sztuczne zachowania i postawy. Postępowi technicznemu - jak wspomniałem - towarzyszy zjawisko mechanomorfizacji ludzi. Nie tylko staramy się doścignąć, a może nawet prześcignąć maszyny pod względem szybkości pracy oraz wydajności, ale też zachowywać się tak, jak one, to znaczy jak najbardziej obiektywnie, czyli, inaczej mówiąc obojętnie wobec zaistniałych sytuacji życiowych (także społecznych) i wobec innych ludzi, kooperantów, towarzyszy pracy, kolegów, a nawet członków rodziny. Nasze stosunki interpersonalne stają się w miarę rozwoju cywilizacji technicznej coraz bardziej oziębłe i bezduszne, a nasze zaangażowanie emocjonalne ulega stopniowej i zauważalnej redukcji. Oprócz tego narzucone nam przez postęp techniczny niezwykle szybkie tempo życia ogranicza czas, jaki powinniśmy poświęcać naszym innym ludziom, co również przyczynia się do redukcji empatii. Akceleracja tempa życia w znacznym stopniu uniemożliwia nam zastanawianie się nad wyborami, a szybko zmieniające się sytuacje wymuszają podejmowanie bardzo szybkich decyzji. W związku $\mathrm{z}$ tym dokonujemy wyborów, także moralnych, w czasie, który nie pozwala na zastanowienie się nad tym, czy są one poprawne, skuteczne i słuszne. Dlatego kierujemy się utartymi szablonami, najprostszymi regułami myślenia logiczne- 
go oraz stereotypami i chętnie korzystamy z podpowiedzi maszyn myślących za nas. $W$ procesie decyzyjnym odwołujemy się więc do artefaktów należących do sfery kultury duchowej (stereotypy) oraz materialnej (roboty, komputery). $W$ rezultacie, nasze zachowanie przypomina zachowanie się maszyn - w coraz większym stopniu staje się ono indyferentne, zimne i bezosobowe. Takie samo staje się nasze odnoszenie się do świata zewnętrznego (do przyrody i społeczeństwa), czyli nasze postawy, relacje i związki. I wskutek stajemy się coraz bardziej odizolowani i czujemy się wyobcowani. A w związku z tym współtowarzyszy, przyjaciół i ulubieńców zmuszeni jesteśmy poszukiwać wśród artefaktów: „braci robotów", wyposażonych w mikroprocesory urządzeń naśladujących zwierzątka (np. tamagotchi) i ludzi (np. „lalki” służące do zaspokajania popędu seksualnego). I rzeczywiście znajdujemy ich coraz więcej w świecie artefaktów dzięki producentom chętnie zaspokajającym najbardziej wymyślne potrzeby. A co ciekawe, obcowanie $z$ artefaktami - substytutami ludzi i zwierząt - bywa mniej uciążliwe niż z rzeczywistymi istotami żywymi, nie wymaga tylu starań oraz zabiegów, dostarcza porównywalnych przyjemności i dlatego jest coraz bardziej akceptowane. Jest i druga strona medalu: obcowanie $\mathrm{z}$ takimi sztucznymi istotami prowadzi do tego, że z naturalnymi istotami żywymi obchodzimy się tak, jak ze sztucznymi, to znaczy, gdy się nam znudzą, możemy wyrzucić je na śmietnik albo zniszczyć.

Po trzecie, sztuczna, wirtualna rzeczywistość. Technika komputerowa powołała do życia świat wirtualny - wirtualne byty i sytuacje. Niby jest to świat rzeczywisty, bo przecież przedstawiany jest na ekranach komputerów i postrzegany za pomocą zmysłów. Mimo to jest to świat nierealny, ponieważ są to byty, zjawiska i sytuacje zmyślone, dla których brak naturalnych korelatów. Obcowanie z światem wirtualnym, który jest również artefaktem, pociąga za sobą przynajmniej dwa skutki. Po pierwsze, redukuje nasz kontakt ze światem naturalnym z żywymi ludźmi i realnymi „życiowymi” sytuacjami. Im więcej czasu spędzamy z komputerem, tym mniej doświadczamy środowiska realnego „naturalnego”. Po drugie, intensywny i ciągły kontakt ze światem wirtualnym rozmywa granicę między fikcją (wirtualności) a realnością. Wskutek tego nie za bardzo wiemy (szczególnie dzieci), co naturalne, a co wymyślone i coraz bardziej skłonni jesteśmy przypisywać wirtualnym, zazwyczaj fikcyjnym postaciom, zjawiskom i sytuacjom walor realności. W konsekwencji często zachowujemy się w realnym świecie oraz w realnych sytuacjach tak, jakbyśmy byli w świecie wirtualnym (fikcyjnym), co pociągać może za sobą niezbyt dobre skutki. Mieszanie świata wirtualnego z realnym i utożsamianie ich w jakimś realny różni się od wirtualnego, że obowiązują w nim inne prawa niż te, jakie wymyślili programiści informatyczni i różni inni twórcy fikcji.

Niewątpliwie, $\mathrm{z}$ tworzeniem fikcji oraz złudzeń mieliśmy do czynienia „od zawsze”. Było to skutkiem myślenia mitycznego i magicznego, wierzeń religijnych, ideologii, poglądów filozoficznych, a także literatury fantastycznej (science 
fiction) oraz bajkopisarstwa. Ludzie kreowali rozmaite fikcje i chętnie dawali się łudzić co do ich realnego istnienia i realnych mocy sprawczych. Niemniej jednaj oddziaływanie fikcji na świadomość ludzi było nieporównywalnie mniejsze dawniej niż obecnie. A to przede wszystkim za sprawą masowego korzystania z komputerów i Internetu, chociaż znaczny udział w tym dziele ma również telewizja oraz masowa produkcja książek i czasopism. Trudno ocenić, czy dawniej tworzono mniej fikcji niż dzisiaj. Jednak jedno jest pewne: upowszechnianie fikcji poprzez gry komputerowe, komiksy, reklamy, filmy itp., częstotliwość ich pokazywania i oglądania, niezwykła ekspresja obrazów i łatwość dostępu (sięgania) do nich jest teraz nieporównywalnie większa. Dzięki temu zwielokrotnione jest oddziaływanie świata wirtualnego na naszą świadomość oraz psychikę. Coraz mocniej wirtualność odciska tu swoiste piętno.

\section{Biologiczna degradacja człowieka wspomaganego artefaktami}

W wyniku postępu technicznego mamy do dyspozycji coraz więcej urządzeń technicznych wspomagających nas w różnych funkcjach oraz sytuacjach życiowych, czyli takich, które wcześniej nazwałem „protezami”. Wskutek tego, że te protezy są coraz łatwiej dostępne w skali masowej i że chętnie się nimi posługujemy, ponieważ ułatwiają nam życie, a każdy chce łatwo żyć, przekształcamy się dobrowolnie i masowo w kaleki, które nie potrafią się obyć bez różnego rodzaju protez. W związku z tym pojawia się pewien problem etyczny, a mianowicie kwestia odpowiedzialności za czynienie nas kalekami w wyniku postępu technicznego, który napędzany jest siłami konsumpcjonizmu oraz za wynikającą stąd biologiczną degradację ludzi korzystających masowo z protez. A w takim razie tym szczególnego znaczenia nabiera też sprawa odpowiedzialności za dalsze losy ludzkości oraz za przetrwanie gatunku ludzi, którzy staja się coraz bardziej ułomnymi istotami, bo niezdolnymi do życia bez moźliwości korzystania z protez.

Wspomniałem już o tym, że słowo „proteza" rozumiem w szerokim sensie, to znaczy jako wszystko to, co wykonuje za nas różne czynności. Przypuszczam, że techniczne wspomaganie ludzi w postaci dostarczania im coraz większej liczby i coraz bardziej skomplikowanych protez, jest zjawiskiem szkodliwym, ponieważ przyczynia się do ich degradacji biologicznej. Wbrew pozorom, w miarę doskonalenia się, dzięki wysiłkowi inżynierów i naukowców, ulegamy nie tylko degradacji biologicznej, ponieważ jesteśmy coraz słabsi fizycznie i intelektualnie, ale też zostajemy poddani progresywnemu procesowi dehumanizacji rozumianej jako redukcja gatunkowych cech ludzkich. W ten sposób postęp nauki i techniki, z którym wiązaliśmy wielkie nadzieje od czasów Oświecenia, w rzeczywistości rozczarowuje nas dzisiaj, ponieważ wywołuje nową formę kryzysu ekologicznego oraz zmniejsza szansę przeżycia.

Postęp wiedzy i techniki realizuje dwie podstawowe funkcje: po pierwsze, umożliwia nam przeżycie, a po drugie, czyni nasze życie łatwiejszym. Pierwsza 
z nich ma znaczenie egzystencjalne dla ludzi. Bez rozwijania wiedzy i techniki nie bylibyśmy i nadal nie jesteśmy w stanie istnieć. Druga z nich ma tylko znaczenie funkcjonalne.

Pod względem cielesnym gatunek ludzki nie wypada korzystnie na tle wielu innych gatunków istot żywych. Mamy mniejsze możliwości recepcyjne narządów zmysłowych (słabszy wzrok, słuch, dotyk) oraz dysponujemy mniejszą siłą naszych mięśni. Jakby w zamian za to natura wyposażyła nas w niezwykłą siłę intelektu. Naszą jedyną oraz najskuteczniejszą bronią w walce o byt i przetrwanie jest intelekt oraz jego wytwory: wiedza i technika. Dlatego chcąc przetrwać, czyli zwyciężać w walce o byt przyrodniczy i społeczny, musieliśmy przede wszystkim rozwijać wiedzę i technikę. ${ }^{9}$ Z jednej strony, technika wyposażała ludzi najpierw w narzędzia potrzebne do walki z innymi gatunkami, a później - do walki z innymi ludźmi, z tzw. wrogami. W ten sposób wiedza i technika stały się instrumentem w międzygatunkowej oraz w wewnątrzgatunkowej walce o byt - o biologiczne i społeczne przetrwanie. Z drugiej strony, technika dostarcza ludziom urządzeń, które przyczyniają się do wzrostu komfortu życia i dzięki którym nie musimy się zbytnio męczyć. W pierwszym rzędzie budowano i doskonalono proste i złożone maszyny, które odciążały ludzi od wysiłku cielesnego. W tym zakresie doszliśmy już do perfekcji. Maszyny (automaty oraz roboty) przejęły prawie wszystkie funkcje cielesne ludzi i wykonują je o wiele bardziej wydajnie i precyzyjnie. Z kolei myśl naukowa i techniczna rozwijała się w kierunku zastępowania czynności intelektualnych ludzi przez maszyny. W tej dziedzinie zaznaczył się niebywały postęp w dwudziestym wieku. Automaty, komputery i roboty odciążyły ludzi od wysiłku intelektualnego, od wykonywania bardzo wielu operacji intelektualnych w zakresie myślenia logicznego, kalkulacji a nawet w jakiejśs mierze twórczości artystycznej. Postęp wiedzy i techniki zmierza ku temu, by urządzenie techniczne mogło zastąpić człowieka we wszystkich jego funkcjach życiowych - cielesnych i intelektualnych. Realizując tę tendencję postępu popadliśmy w niezwykle silną zależność egzystencjalną i funkcjonalną od techniki. Nasza cywilizacja stała się zależna od cudownych zdolności nauki i techniki bez względu na to, czy oceniamy ten fakt pozytywnie, czy negatywnie. Niewątpliwie, wiele urządzeń i wytworów technicznych jest doskonalszych od nas z różnych względów. Urządzenia techniczne są w stanie naśladować nie tylko różne zwierzęta (jak na przykład w latach pięćdziesiątych ubiegłego wieku słynny żółw Ashbiego), ale i człowieka. Szybkimi krokami zbliżamy się do skonstruowania sztucznego człowieka, czyli atrapy podobnej do cyborga (cybernetic organism). Kiedy dojdzie do tego, będzie to chyba oznaczać koniec dalszego rozwoju techniki w tym kierunku, bo co jeszcze miałyby naśladować urządzenia techniczne? Od pewnego czasu w wyniku pogoni za bogactwem rozpoczęło się narastające

Zob. D. Kindersley, Der Mensch. 2004. 
dążenie ludzi do dorównania urządzeniom technicznym. W związku z tym naszym zadaniem stało się naśladowanie wytworzonych przez siebie produktów techniki oraz maksymalne upodobnienie się do nich. Dlatego wydaje mi się, że ewolucja gatunku ludzkiego będzie teraz zmierzać do coraz większej mechanomorfizacji ludzi. A zatem, rozpoczął się proces przeciwny do antropomorfizacji maszyn. Taka tendencja ewolucji podyktowana jest względami ekonomicznymi, w szczególności obłąkańczą pogonią za zyskiem. Staramy się uzyskać takie parametry odporności, precyzji, szybkości, wielofunkcyjności, pamięci itp., jakie właściwe są najwyżej rozwiniętym maszynom - komputerom i robotom. Dlatego od pewnego czasu kontynuujemy szaleńczy wyścig z techniką nie zważając na zagrożenia, jakie $z$ tego wynikają.

Tak antropomorfizacja maszyn jak i mechanomorfizacja ludzi przyczyniają się do biologicznej degradacji gatunku ludzkiego. W pierwszym przypadku chodzi przede wszystkim o to, że jeśli przekazujemy maszynom swoje istotne cechy gatunkowe, to sami się ich wyzbywamy, a przynajmniej przyczyniamy się do znacznej redukcji tych cech. Stopniowa redukcja lub utrata przez ludzi swych istotnych cech (gatunkowych) nie oznacza nic inne, jak odczlowieczenie. Natomiast $w$ drugim przypadku chodzi o to, że coraz większe upodobnianie się ludzi do maszyn czyni z nich w końcu istoty funkcjonujące tak, jak maszyny, (tzn. kierujące się racjonalnością zredukowaną do zwykłej kalkulacji) oraz ogranicza ich sferę duchową i emocjonalną. Sprawa jest dosyć dziwna. Z jednej strony, po to rozwijaliśmy racjonalność i powinniśmy nadal rozwijać ją jako specyficzną cechę gatunkową (jesteśmy przecież ex definitione istotami rozumnymi!), aby jeszcze bardziej stawać się ludźmi. Z drugiej strony, im bardziej dzięki technice stajemy się racjonalni, tym bardziej ulega redukcji inna nie mniej istotna cecha gatunkowa ludzi - duchowość, chociaż nie wydaje się to konieczne i jest kwestią dyskusyjną. Wiemy też, że rozwój racjonalności, i związany z tym rozwój wiedzy i techniki, przyczynił się do wielu szkodliwych doświadczeń ludzkości, jak na przykład do ludobójstwa w obozach koncentracyjnych, holocaustu, powstania broni masowej zagłady i znacznej degradacji środowiska życia. ${ }^{10} \mathrm{Z}$ tej racji w imię dobra ludzkości należałoby może zaprzestać postępu racjonalności i spowolnić Pochód Rozumu. Tak czy inaczej, im więcej naszych zracjonalizowanych czynności przejmują maszyny, tym mniej pozostaje ich dla nas. Odbija się to przede wszystkim na procesach decyzyjnych. Stopniowo eliminowany jest z procesu decyzyjnego czynnik osobowy (subiektywny), ponieważ większość decyzji podejmujemy korzystając z urządzeń technicznych. To tak, jakby maszyny podejmowały decyzje za nas kierując się zwykłymi algorytmami i zimną, bezwzględną kalkulacją. Przy tym odpowiedzialnością za złe decyzje obarczamy maszyny, bo

10 Zob. J .A. Wojciechowski, Od ewaluacji wiedzy sensorycznej do Oświęcimia i Archipelagu Gułag, w: Wokót ekofilozofii (red. A. Papuziński, Z. Hull), Bydgoszcz 2001. 
wygodnie jest zwalać winę nie na siebie. O wiele gorsze skutki pociąga za sobą przekazywanie maszynom jeszcze innych funkcji intelektualnych związanych ze sferami uczuć, wiary i twórczości. W wyniku poznawania mechanizmów funkcjonowania tych sfer w strukturze mózgu, co jest zasługą współczesnej neurofizjologii, jesteśmy w stanie konstruować ich odpowiedniki oraz substytuty techniczne. To umożliwia wyposażanie urządzeń technicznych w jeszcze inne cechy właściwe tylko ludziom. Dlatego już niewiele pozostało w nas tego, co typowo i wyłącznie ludzkie i czego nie dałoby się zastąpić artefaktami. Dlatego antropomorfizacja maszyn zdaje się dobiegać końca. Ale czy dobiega też kresu proces mechanomorfizacji ludzi? Niewątpliwie, usiłując dorównać komputerom i robotom i rywalizując z techniką, stajemy się coraz bardziej podobni do maszyn. Zachowujemy się i działamy w sposób machinalny, staramy się wykorzystywać wszystkie wolne moce naszego organizmu i intelektu, by stać się tak wydajni (w sensie ekonomicznym lub technicznym), jak maszyny i dajemy się łatwo manipulować i programować za pomocą różnych sposobów oraz instrumentów manipulacji społecznej. A wszystko to dlatego, że wraz ze wzrostem racjonalności tracimy poczucie krytycyzmu oraz zdrowy rozsądek. Zamiast myśleć krytycznie i refleksyjnie, staramy się myśleć za pomocą algorytmów logiki formalnej - właśnie tak jak „myślą” maszyny.

W rezultacie ulegamy globalnej standaryzacji w efekcie dokonujących się procesów uświatowienia w zakresie sposobu bycia, zachowania się, stylu myślenia, wyrażania się, odczuwania, mody itd. W wyniku globalizacji stopniowo przekształcamy się w „tłum światowy” i jako jednostki podlegamy coraz większemu umasowieniu i uśrednieniu. Tracimy własną indywidualność i niepowtarzalność na rzecz przeciętności i naśladownictwa. Redukujemy swoje cechy indywidualne, dzięki którym jesteśmy istotami jedynopojawieniowymi. W rezultacie stajemy się istotami zastępowalnymi w populacji podobnie jak w technice elementy maszyn, które można dowolnie wymieniać A być może w niedalekiej przyszłości w wyniku klonowania będziemy istotami dającymi się też powielać. W tej sytuacji pytanie o to, czy w miarę wspomagania technicznego zjawiska te świadczą o dehumanizacji i degradacji gatunku ludzkiego wydaje się retoryczne.

Degradacja biologiczna polegająca na dehumanizacji związanej z redukcją cech typowo ludzkich wskutek zastępowania ludzi przez maszyny oraz ze wspomaganiem ich przez nowoczesną technikę jest faktem bezspornym. A egzystencjalne uzależnienie ludzi od techniki implikuje skutki wysoce niepokojące. Niepokój ten rodzi choćby takie oto problemy i dylematy natury bioetycznej:

1. Czy powinniśmy pogłębiać zależność egzystencjalną między ludźmi i techniką?

2. Do jakiego stopnia powinniśmy wspomagać technicznie życie ludzi?

3. Czy należy za wszelką cenę utrzymywać ludzi przy życiu za pomocą różnych protez? 
4. Czy postęp techniczny powinien czynić ludzi jeszcze bardziej ułomnymi, czy odporniejszymi?

Na te pytania trudno odpowiedzieć w sposób jednoznaczny nie dowołując się do jakiejś etyki absolutnej, czyli takiej, której nakazy lub zakazy nie dopuszczają wyjątków. Ale z taka etyka nie obowiązuje już powszechnie we współczesnym świecie. Żyjemy przecież w warunkach pluralizmu i relatywizmu etycznego, w świecie niezwykle szybko zmieniającym się, niestabilnym ${ }^{11}$, pozbawionym trwałych oraz niezawodnych punktów oparcia. W takim świecie normy etyczne i hierarchie wartości powinny tak szybko ulegać zmianom, by mogły nadążać za zmianami dokonującymi się w naszym środowisku życia i by sprostać nowym wymogom tego środowiska. ${ }^{12}$ To jednak jest nieosiągalne, ponieważ współczesny świat jest coraz mniej przewidywalny, zwłaszcza, gdy o naszej przyszłości decydować będą bardziej roboty aniżeli ludzie. Działają one nieporównywalnie szybciej niż ludzie, szybciej podejmują wybory i są w stanie szybciej programować przyszłość niż potrafimy ją sobie wyobrazić. Mimo ogromnego postępu wiedzy i techniki nie jesteśmy w stanie dokładnie przewidzieć zmian ani sytuacji, do których mielibyśmy dostosować normy etyczne.

Ochrona życia za pomocą techniki (protez) czyni z nas istoty wciąż bardziej ułomne, a nasze życie - coraz bardziej kruchym, niepewnym i ryzykownym. Nadmiernemu wspomaganiu technicznemu życia przez coraz bardziej skomplikowane protezy towarzyszy wzrost zagrożenia życia, ponieważ im bardziej skomplikowane jest urządzenie techniczne, tym większe jest ryzyko jego awarii. Wiadomo przecież, że bardziej skomplikowane urządzenia techniczne wymagają zapewnienia odpowiednich parametrów środowiska do ich poprawnego funkcjonowania i to w sposób rygorystyczny. Nie tolerują one zbyt wielkich odchyleń od założonych wartości. Dosyć trudno jest utrzymać te parametry w normie i dlatego w przypadku skomplikowanej techniki wzrasta prawdopodobieństwo awarii (chociaż nie tylko z tego powodu). Wskutek tego, rozwój techniki przestał już sprzyjać możliwości przeżycia. Wręcz przeciwnie, czyniąc życie zależnym od coraz bardziej skomplikowanych protez, implikuje wzrost ryzyka przeżycia. Tym samym podstawową funkcją techniki nie jest już zapewnienie możliwości życia ludziom, lecz czynienie ich życia coraz mniej pewnym i bezpiecznym.

11 Zob. J. Blażejewski, Termodynamiczne spojrzenie na funkcjonowanie przyrody - zachowanie etyczne w kontekście środowiskowym [Thermodynamic view on the functioning of nature - Ethical behavior in environmental context], In: Filozoficzne, spoteczne i ekonomiczne uwarunkowania zrównowazonego rozwoju [Philosophical, social and economical determinations of the sustainable development](ed. A.. Pawtowski), Lublin 2004.

12 Zob. W. Sztumski, My, zagubieni w świecie (Przyczynek do filozofi środowiska jako podstawy enwironmentologii), Katowice 2004. 


\title{
Relationship between human and his products in the environmental ethics aspect
}

\begin{abstract}
The subject of ethics should not only be the valuation of different forms of human actions but also the evaluation of the results of them. Talking about the results of human activity, I mean not only the logical effects and consequences, but also material and spiritual products od ur actions, that is different artefacts.

It's impossible to include all the problems and evaluation of all the results of our actions. That is why I come down just to one issue - to the responsibility for excessive intensity of human environment by the new technology products which are used as the assistance to human organism and mind. This type of responsibility fits to environmental ethics which relates to relation between human and environment and this is why it is something new and wider in comparison with traditionally understood moral responsibility usually limited to the relation "human - human". Following issues are taken into consideration in this article: human in artefact environment, threats connected with growth of artefacts in the area of spiritual culture, biological degradation of a man assisted with artefacts.
\end{abstract}

